https://www.journal-imab-bg.org

Original article

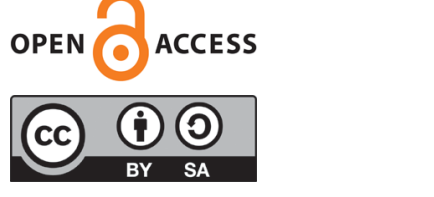

\title{
STUDY OF SERUM OSTEOPROTEGERIN AND RECEPTOR ACTIVATOR OF NUCLEAR FACTOR KAPPA-B LIGAND IN PATIENTS WITH RHEU- MATIC DISEASES
}

\author{
Mariela Geneva-Popova, Stanislava Popova \\ Propaedeutics of Internal Diseases, Faculty of Medicine, Medical University - \\ Plovdiv; \\ Rheumatology, UMHAT "Sveti Georgi" Plovdiv, Bulgaria.
}

\begin{abstract}
Although rheumatological diseases are widespread, they still have an unclear etiology, pathogenesis, and therapy. Researchers are looking for biomarkers associated with inflammatory and degenerative joint diseases. Serum Osteoprotegerin (s-OPG) and serum Receptor Activator of Nuclear Factor Kappa-B Ligand (s-RANKL) have not been studied in patients with Diffuse idiopathic skeletal hyperostosis (DISH), spondylosis, ankylosing spondylitis, and gout.

The aim of this study was to investigate s-OPG and sRANKL in patients with various rheumatic diseases.

Materials and methods: We studied 135 patients with rheumatic diseases, of which 55 were diagnosed with DISH, 50 with spondylosis, 23 with ankylosing spondylitis, 7 with gout, and 25 were a control group. s-OPG and s-RANKL, serum calcium, ionized calcium, serum phosphorus, alkaline phosphatase, uric acid, urea, creatine, and serum osteocalcin were tested using the ELISA method in the Clinical Laboratory of "St. George" University Hospital, Plovdiv. The results were processed using the statistical program SPSS ver 26, with significance $\mathrm{p}<0.05$.

Results: Patients with DISH and ankylosing spondylitis had higher levels of s-OPG, s-RANKL, and s-OPG/s-RANKL ratio than the control group $(\mathrm{p}<0.05)$. The $\mathrm{s}-\mathrm{OPG} / \mathrm{s}-\mathrm{RANKL}$ ratio in patients with spondylosis and gout was lower than in patients with DISH and ankylosing spondylitis $(\mathrm{p}<0.05)$. There are strong correlations between s-OPG, s-RANKL, and the biochemical parameters related to bone metabolism (serum calcium, ionized calcium, serum phosphorus, alkaline phosphatase, uric acid, urea, creatine, and serum osteocalcin) $(\mathrm{p}<0.05)$.

Conclusion: Our studies show that changes in bone metabolism are similar in patients with DISH and ankylosing spondylitis. Further research is needed to look for a common pathogenetic pathway linking degenerative and inflammatory rheumatic diseases of the axial skeleton.
\end{abstract}

Keywords: serum osteoprotegerin, s-RANKL, rheumatic diseases,

\section{INTRODUCTION}

The serum Osteoprotegerin (s-OPG) and the serum Receptor Activator of Nuclear Factor-kB Ligand (s-RANKL) are involved in the pathophysiology of many rheumatic diseases such as ankylosing spondylitis (AS) and rheumatoid arthritis (RA), but little is known about their involvement in the pathogenesis of diffuse idiopathic skeletal hyperostosis (DISH), spondylosis (SP), and gout [1, 2, 3, 4]

s-OPG was initially discovered as a key regulator in bone metabolism and has recently been discovered in the vascular system. s-OPG functions as a soluble receptor for the receptor activator of nuclear factor kappa B ligand, which stimulates osteoclast differentiation and activation. Therefore, by binding and neutralizing RANKL, s-OPG inhibits osteoclastogenesis and increases bone mineral density $[5,6$, $7,8]$.

$\mathrm{s}$-OPG is a cytokine that belongs to the TNF-receptor family due to a homologous sequence with the other members; however, unlike them, it does not have the classical hydrophobic transmembrane domain $[9,10]$. s-OPG is a secretory glycoprotein with monomeric $(60 \mathrm{kD})$ and disulfidebonded homodimeric forms $(120 \mathrm{kD})[6,11]$. Its molecule consists of 401 amino acid residues that form seven structural domains. Domains 1-4 at the amino-terminus are similar to the extracellular domains of other TNF receptors and determine the inhibition of osteoclastogenesis $[6,11,12]$. Domains 5 and 6 at the carboxyl-terminus contain regions that are homologous to apoptosis mediators, such as apoptosisinducing ligand receptors, similar to TNF. Domain 7 has a heparin-binding region characteristic of peptide growth factors and signaling molecules, as well as an unpaired cysteine residue required for disulfide bonding and dimerization $[6$, $11,13]$.

Two s-OPG ligands are known, both belonging to the TNF family:

1) receptor activator of nuclear factor-kB ligand (RANKL) [14]

2) tumor necrosis factor-related apoptosis-inducing ligand (TRAIL) [14]

s-OPG acts as a soluble receptor for RANKL, which stimulates osteoclast differentiation and activation $[14,15]$. By binding to RANKL, osteoprotegerin blocks its effects, 
prevents bone loss, and increases bone mineral density.

Browner et al. found that elevated plasma levels of sOPG in women with diabetes was associated with both increased cardiovascular mortality and overall mortality [16]. This finding has since been supported by data from other modern studies. High plasma s-OPG has been found in type 1 and type 2 diabetics, and an association between s-OPG, glycated hemoglobin, changes in lipid status, markers of systemic inflammation, and micro- and macrovascular damage has been found [16].

The Osteoprotogerin/RANKL/RANK system is essential for the formation of multinucleated osteoclasts from precursor monocytes/macrophage cells [17, 18]. Their activation and apoptosis was discovered in 1997 and has not been studied in DISH, spondylosis, and gout [5, 19, 20].

According to Krysturkova et al., the blood levels of osteoprotogerin in patients with DISH $(n=71)$ and patients with osteoarthrosis ( $n=44$ studies) were not different when compared to controls $(n=116)$ [21].

RANKL is a transmembrane molecule expressed by mesenchymal cells and lymphocytes [5, 19]. RANKL binds to RANK on hematopoietic cells and activates cytoplasmic adapter proteins $[22,23]$. This, in turn, activates downstream signaling pathways comprised of nuclear factor kappa-lightchain-enhancer of activated B cells and nuclear factor of activated T-cells cytoplasmic $1[22,23]$. RANKL is neutralized by its soluble OPG receptor [22, 23].

s-OPG is secreted by osteoblasts and osteogenic stromal stem cells; it protects the skeleton from excessive bone resorption by binding to RANKL and preventing its interaction with RANK. Therefore, the RANKL/OPG ratio in bone marrow is an important determinant of both normal and diseased bone mass [24, 25].

The aim of this study was to investigate s-OPG and sRANKL in patients with various rheumatic diseases and to determine their correlation with indicators of bone metabolism.

\section{Subject of observation:}

The subjects of the study were patients with the following rheumatic diseases: AS, DISH, SP and gout.

\section{Research approach}

1. Perspective approach of suitable patients from 2013-2020 (the study included patients hospitalized at the University Clinic of Rheumatology at "St. George" Hospital, Plovdiv).

2. Collection of comprehensive clinical data on patients, which was coded and available to the research team. The patients were informed of this. The individual results, indices, and functional scales were calculated.

3. Determination of biochemical parameters and indicators of bone metabolism.

4. Statistical data processing.

\section{Study design}

"Case-control" study

Data regarding the demographic characteristics of the patients was collected, and a physical examination was performed with an emphasis on changes in the musculoskeletal system. Results from both laboratory and imaging methods were analyzed. The data from each patient was summarized in a protocol prepared for the purposes of this study. The data collected from the control subjects was compared to that of patients with rheumatic diseases.

\section{Units of observation:}

We studied 135 patients with rheumatic diseases, of which 55 were diagnosed with DISH, 23 with AS 50 with SP, 7 with gout. We also studied 25 control individuals with uniform sex and age. The study was performed at the Department of Propaedeutics of Internal Medicine, Medical University - Plovdiv. The two groups - patients with rheumatic diseases and the control group, were statistically uniform in terms of the main blurring factors, gender and age.

\section{METHODS}

Tools for evaluation of laboratory results - the complete blood count was determined with a multiparameter device, in compliance with the manufacturer's requirements, in the Central Institute Laboratory. The methods and reference values used are as follows (Table 1):

Table 1. Distribution of laboratory tests, methods, and reference values used in the study.

\begin{tabular}{|l|l|c|}
\hline \multicolumn{1}{|c|}{ Parameter } & \multicolumn{1}{|c|}{ Method } & Reference value \\
\hline Triglycerides & Enzyme method with reading the automatic analyzer Konelab 60i, USA & 0,6-1,71 mmol/1 \\
& CV in time 2,34-4,29 & Enzyme colorimetric method with Uricase / PAP-Trinder, company kits, \\
reading of Konelan 60i, USA, & male 208-398 mkmol/1 \\
& CV in time 3.84\%, & female149-363 mkmol/L \\
\hline Urea & $\begin{array}{l}\text { Enzyme UV-test, with Urease / GLDH, kinetic, reading of } \\
\text { Konelab 60i,USA, }\end{array}$ & $\begin{array}{l}\text { male 3,2-8,9 mmol/1 } \\
\text { female 2,6-7,2 mmol/ }\end{array}$ \\
\hline
\end{tabular}




\begin{tabular}{|l|l|l|}
\hline Creatinine & $\begin{array}{l}\text { Colormethyl kinetic method of Jaffe, branded kits, reading of Konelab } \\
\text { 60i, USA, } \\
\text { CV up to 5.1\% }\end{array}$ & $\begin{array}{l}\text { male 74-134 mkmol/1 } \\
\text { female 44-96 mkmol/1 }\end{array}$ \\
\hline $\begin{array}{l}\text { Alkaline } \\
\text { phosphatase }\end{array}$ & $\begin{array}{l}\text { Colorimetric kinetic method, company tests, reading of } \\
\text { Konelab 60i, USA, } \\
\text { CV up to 5,10\% }\end{array}$ & $98-279 \mathrm{U} / \mathrm{L}$ \\
\hline $\begin{array}{l}\text { Total calcium in } \\
\text { blood and urine }\end{array}$ & Colorimetric method, company test kits, reading on Konelab 61i, USA, & Serum 2,12-2,62 mmol/1, \\
\hline $\begin{array}{l}\text { Serum } \\
\text { phosphorus }\end{array}$ & $\begin{array}{l}\text { Colorimetric method, company test kits, reading on Konelab 61i, USA, } \\
\text { CV 4.40\% }\end{array}$ & Urine 2,5-4,4 mmol/1 \\
\hline $\begin{array}{l}\text { Ionized } \\
\text { calcium }\end{array}$ & $\begin{array}{l}\text { Direct potentiometry by ion selective erythrodes, company standards, } \\
\text { reading of Konelab 60i, USA, }\end{array}$ & $1,06-1,31 \mathrm{mmol} / \mathrm{l}$ \\
& CV up to 2.3\% & \\
\hline
\end{tabular}

s-OPG was studied with the kit Human Osteoprotegerin Instant ELISA - BMS2021INST, Vienna, Austria. The determination of OPG was performed by enzymelinked immunosorbent "sandwich" method, with a kit of the company eBioscience, in University Hospital "St. Georgi" - Plovdiv, using serum prepared for testing of sOPG. Measurement was done on an ELISA-reader (SitioMicroplate reader, Seac, Italy) at $\lambda 450 \mathrm{~nm}$ (reference $\lambda$ $620 \mathrm{~nm}$ ). All of the manufacturer's requirements were strictly observed. Analytical reliability: The monoclonal anti-s-OPG antibody has a high selective affinity for human osteoprotogerin. Sensitivity - detectable minimum $15.60 \mathrm{ng} / \mathrm{ml}$, determined by $3 \mathrm{SD}$ principles of 0 variants. Reproducibility: Non-reproducibility in a series: in the low region $\mathrm{CV}<6$, in the high $\mathrm{CV}<6.5$ Non-reproducibility in time: in the low region $\mathrm{CV}<10 \%$ in the high $\mathrm{CV}$ $<9 \%$.

s-RANKL was studied using kit Cat N RD193004200R Human s-Rankl, total-free and bound sRANKL, Germany. The determination of s-RANKL was performed by enzyme-linked immunosorbent "sandwich" method, with a kit of the company BioVendor Research and Diagnostic Products in University Hospital "St. Georgi" - Plovdiv, using serum prepared for testing of sRANKL. Measurement was done on an ELISA-reader (Sitio-Microplate reader, Seac, Italy) at $\lambda 450 \mathrm{~nm}$ (reference $\lambda 620 \mathrm{~nm}$ ). All of the manufacturer's requirements were strictly observed. Analytical reliability: The monoclonal anti-RANKL antibody has a high selective affinity for human RANKL. Sensitivity - detectable minimum - $1,200 \mathrm{ng} / \mathrm{ml}$, determined by $3 \mathrm{SD}$ principles of 0 variants. Reproducibility: Non-reproducibility in a series: in the low region $\mathrm{CV}<5$, in the high $\mathrm{CV}<6.5$ Non-reproducibility in time: in the low region $\mathrm{CV}<10 \%$ in the high $\mathrm{CV}<9 \%$.
Serum osteocalcin (s-OC) was studied using the Human Osteocalcin Instant ELISA kit - BMS2020INST, Vienna, Austria. Evaluation of s-OC levels was performed by the enzyme-linked immunosorbent "sandwich" method, with a kit from the company eBioscience, using serum prepared for testing s-OC, at the University Hospital "St. George", Plovdiv. Measurement was done using an ELISA-reader (Sitio-Microplate reader, Seac, Italy) at $\lambda 450$ $\mathrm{nm}$ (reference $\lambda 620 \mathrm{~nm}$ ). All of the manufacturer's requirements were strictly observed. Fluctuations of 2.3-3.6 with a mean of $3.0 \mathrm{mg} / \mathrm{ml}$ were determined from 8 randomly selected controls. Analytical reliability: The monoclonal anti-s-OC antibody has a high selective affinity for human osteocalcin. Sensitivity - detectable minimum - 1,200 $\mathrm{ng} / \mathrm{ml}$, determined by $3 \mathrm{SD}$ principles of 0 variants. Reproducibility: Non-reproducibility in a series: in the low region $\mathrm{CV}<7$, in the high $\mathrm{CV}<6.5$ Non-reproducibility in time: in the low region $\mathrm{CV}<10 \%$ in the high $\mathrm{CV}<7 \%$.

\section{Statistical methods:}

The collected data was checked, coded, and entered into a computer database for further statistical grouping, recoding, and analysis. Descriptive analyzes and correlation analyzes were used in the statistical processing of the data. The statistical program SPSS ver 26 was used.

\section{RESULTS}

s-OPG and s-RANKL were studied in patients with rheumatic diseases and in the control group. The mean values of s-OPG (Table 2) were significantly higher in patients with DISH and AS compared to the results in patients with $\mathrm{SP}$, gout, and the control group $(\mathrm{p}<0.01)$. The highest values of s-OPG were observed in patients with AS. 
Table 2. s-OPG of patients with DISH, SP, gout, AS, and controls, ng/ml.

\begin{tabular}{|l|c|c|c|c|c|}
\hline \multirow{2}{*}{ Disease } & Patients & \multirow{2}{*}{$\bar{n}^{*}+\mathrm{Se} * *$} & \multicolumn{2}{|c|}{ Mean value } & \multirow{2}{*}{ Sd*** } \\
\cline { 4 - 5 } & $\mathrm{n}$ & & Min & Max & \\
\hline DISH & 55 & $14,7 \pm 3,310$ & 0,12 & 117 & 24,548 \\
\hline AS & 23 & $21,52 \pm 11,09$ & 0,1 & 242,1 & 53,18 \\
\hline SP & 50 & $7,58 \pm 2,66$ & 0,3 & 129 & 18,87 \\
\hline Gout & 7 & $9,12 \pm 6,91$ & 0,98 & 50,5 & 18,3 \\
\hline $\begin{array}{l}\text { Control group up to } \\
30 \text { years of age }\end{array}$ & 10 & $5,04 \pm 2,47$ & 0,1 & 25,5 & 7,82 \\
\hline $\begin{array}{l}\text { Control group over } \\
31 \text { years of age }\end{array}$ & 15 & $11,89 \pm 3,820$ & 0,98 & 58,5 & 14,79 \\
\hline
\end{tabular}

$* \bar{x}$ - mean value, $* * \mathrm{Se}$-mean deviation error, $* * * \mathrm{Sd}-$ mean deviation

There are individual patients with DISH, AS, and SP who have s-OPG values significantly above the group mean. For example, the mean s-OPG value in patients with DISH is $14.7 \pm 3.310 \mathrm{ng} / \mathrm{ml}$, and there is a patient with a level of $117.00 \mathrm{ng} / \mathrm{ml}$; the mean s-OPG value in patients with AS is

Fig. 1. Individual values of s-OPG in patients with DISH

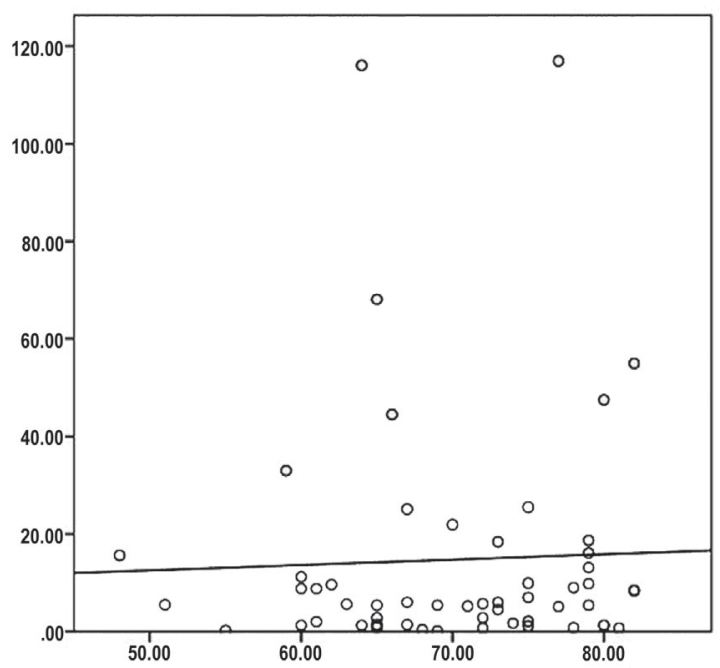

It was found that in healthy controls, the level of sOPG decreases with age, in contrast to s-OPG levels in patients with DISH and AS. The correlation between s-OPG
$21.52 \pm 11.09 \mathrm{ng} / \mathrm{ml}$, there is a patient with a s-OPG level of $242.10 \mathrm{ng} / \mathrm{ml}$. The mean individual levels of s-OPG in patients with DISH and AS gradually increased with age, while the values of this indicator decreased in patients with SP and in the adult controls $(\mathrm{p}<0.05)$ (Figure 1 and 2).

Fig. 2. Individual values of s-OPG in control groups

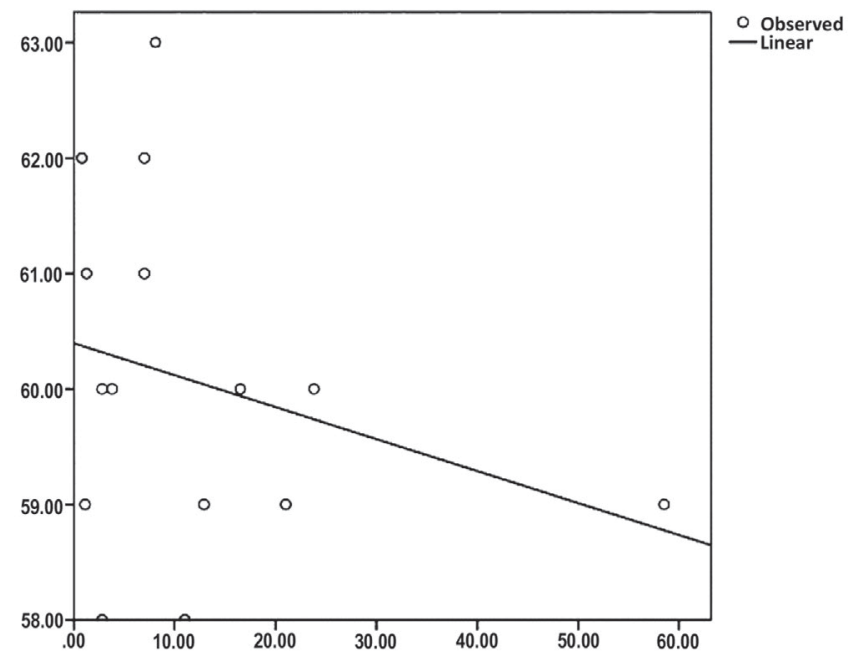

in patients with DISH, AS, SP, gout, and the biochemical parameters are presented in Table 3.

Table 3. Correlation between s-OPG, biochemical results, and indicators of bone metabolism $\left(\mathrm{R}_{\mathrm{x}, \mathrm{y}}\right)$ and their reliability in patients with rheumatic diseases

\begin{tabular}{|l|c|c|c|c|c|c|c|c|}
\hline Indicators & $\begin{array}{c}\mathrm{DISH} \\
\mathrm{R}_{\mathrm{x}, \mathrm{y}}\end{array}$ & $\begin{array}{c}\mathrm{AS} \\
\mathrm{R}_{\mathrm{x}, \mathrm{y}}\end{array}$ & $\begin{array}{c}\mathrm{SP} \\
\mathrm{R}_{\mathrm{x}, \mathrm{y}}\end{array}$ & $\begin{array}{c}\text { Gout } \\
\mathrm{R}_{\mathrm{x}, \mathrm{y}}\end{array}$ & P1* & $\mathrm{P} 2 * *$ & P3*** & P4**** \\
\hline Serum calcium & 0.85 & 0.81 & 0.78 & 0.82 & $<0.01$ & $<0.01$ & $<0.01$ & $<0.01$ \\
\hline Ionized calcium & 0.82 & 0.85 & 0.79 & 0.76 & $<0.01$ & $<0.01$ & $<0.01$ & $<0.01$ \\
\hline Serum phosphorus & 0.74 & 0.81 & 0.82 & 0.83 & $<0.01$ & $<0.01$ & $<0.01$ & $<0.01$ \\
\hline Alkaline phosphatase & 0.85 & 0.72 & 0.75 & 0.86 & $<0.05$ & $<0.05$ & $<0.05$ & $<0.05$ \\
\hline Uric acid & 0.77 & 0.82 & 0.88 & 0.77 & $<0.05$ & $<0.05$ & $<0.05$ & $<0.05$ \\
\hline Creatinine & 0.31 & 0.40 & 0.31 & 0.44 & $\mathrm{~ns}$ & $\mathrm{~ns}$ & $\mathrm{~ns}$ & $\mathrm{~ns}$ \\
\hline Urea & 0.12 & 0.32 & 0.12 & 0.41 & $\mathrm{~ns}$ & $\mathrm{~ns}$ & $\mathrm{~ns}$ & $\mathrm{~ns}$ \\
\hline
\end{tabular}




\begin{tabular}{|l|l|l|l|l|l|l|l|l|}
\hline s-OC & 0.88 & 0.84 & 0.91 & 0.76 & $<0.05$ & $<0.05$ & $<0.05$ & $<0.05$ \\
\hline s-RANKL & 0.89 & 0.71 & 0.79 & 0.82 & $<0.01$ & $<0.01$ & $<0.01$ & $<0.01$ \\
\hline
\end{tabular}

P1*- reliability of the studied indicator in patients with DISH

$\mathrm{P} 2 * *$ - reliability of the studied indicator in patients with AS

$\mathrm{P} 3 * * *$ - reliability of the studied indicator in patients with SP

$\mathrm{P} 4 * * * *$ - reliability of the studied indicator in patients with gout

There is a significant relationship between s-OPG and serum calcium, ionized calcium, serum phosphorus, alkaline phosphatase, s-osteocalcin, and s-RANKL, but not with uric acid creatinine and urea ( $p>0.05)$, in patients with rheumatic diseases.
The mean values of s-RANKL (Table 4) were highest in patients with DISH, gout, and SP, which was significant when compared to patients with AS and the adult controls $(\mathrm{p}<0.001)$.

Table 4. Results of mean s-RANKL values in patients with DISH, SP, gout, AC, young, and adult controls in pg/ml.

\begin{tabular}{|l|c|c|c|c|c|}
\hline \multirow{2}{*}{ Disease } & Patients & \multirow{2}{*}{$\bar{x}^{*}+\mathrm{Se} * *$} & \multicolumn{2}{|c|}{ Mean value } & \multirow{2}{*}{ Sd*** } \\
\cline { 4 - 5 } & $\mathrm{n}$ & & Min & Max & \\
\hline DISH & 55 & $197,00 \pm 35,90$ & 10 & 1430 & 266,27 \\
\hline AS & 23 & $90,86 \pm 18,542$ & 20 & 430 & 88,92 \\
\hline SP & 50 & $200,60 \pm 66,167$ & 10 & 3200 & 467,85 \\
\hline Gout & 7 & $250,0 \pm 15,076$ & 20 & 500 & 174,54 \\
\hline $\begin{array}{l}\text { Control group up to } \\
30 \text { years of age }\end{array}$ & 10 & $83,00 \pm 14,98$ & 50 & 180 & 47,38 \\
\hline $\begin{array}{l}\text { Control group over } \\
31 \text { years of age }\end{array}$ & 15 & $83,33 \pm 15,076$ & 30 & 250.00 & 58,39 \\
\hline
\end{tabular}

In patients with $\mathrm{SP}$, the highest individual registered value was $3200 \mathrm{pg} / \mathrm{ml}$, which is significantly above average compared to the other subjects.

Patients with DISH had an increased mean value of s-
RANKL compared to patients with AS and controls ( $\mathrm{p}<0.001)$. Their results did not differ significantly from the values of patients with SP and gout ( $\mathrm{p}>0.05)$ (Table5).

Table 5. Correlation between s-RANKL, biochemical results, and indicators of bone metabolism (Rx,y) and their reliability in patients with rheumatic diseases.

\begin{tabular}{|l|c|c|c|c|c|c|c|c|}
\hline Indicators & $\begin{array}{c}\mathrm{DISH} \\
\mathrm{R}_{\mathrm{x}, \mathrm{y}}\end{array}$ & $\begin{array}{c}\mathrm{AS} \\
\mathrm{R}_{\mathrm{x}, \mathrm{y}}\end{array}$ & $\begin{array}{c}\mathrm{SP} \\
\mathrm{R}_{\mathrm{x}, \mathrm{y}}\end{array}$ & $\begin{array}{c}\text { Gout } \\
\mathrm{R}_{\mathrm{x}, \mathrm{y}}\end{array}$ & $\mathrm{P} \boldsymbol{y}^{*}$ & $\mathrm{P} 2 * *$ & $\mathrm{P}$ 3*** & $\mathrm{P} 4 * * * *$ \\
\hline Serum calcium & 0.88 & 0.81 & 0.78 & 0.82 & $<0.01$ & $<0.01$ & $<0.01$ & $<0.01$ \\
\hline Ionized calcium & 0.75 & 0.85 & 0.79 & 0.85 & $<0.01$ & $<0.01$ & $<0.01$ & $<0.01$ \\
\hline Serum phosphorus & 0.82 & 0.81 & 0.74 & 0.83 & $<0.01$ & $<0.01$ & $<0.01$ & $<0.01$ \\
\hline Alcaline phosphatase & 0.84 & 0.72 & 0.74 & 0.76 & $<0.05$ & $<0.05$ & $<0.05$ & $<0.05$ \\
\hline Uric acid & 0.80 & 0.88 & 0.88 & 0.73 & $<0.05$ & $<0.05$ & $<0.05$ & $<0.05$ \\
\hline Creatinine & 0.34 & 0.40 & 0.31 & 0.16 & $\mathrm{~ns}$ & $\mathrm{~ns}$ & $\mathrm{~ns}$ & $\mathrm{~ns}$ \\
\hline Urea & 0.44 & 0.32 & 0.12 & 0.16 & $\mathrm{~ns}$ & $\mathrm{~ns}$ & $\mathrm{~ns}$ & $\mathrm{~ns}$ \\
\hline s-OC & 0.72 & 0.74 & 0.70 & 0.75 & $<0.05$ & $<0.05$ & $<0.05$ & $<0.05$ \\
\hline s-RANKL & 0.89 & 0.77 & 0.76 & 0.82 & $<0.01$ & $<0.01$ & $<0.01$ & $<0.01$ \\
\hline
\end{tabular}

$\mathrm{P} 1 *_{-}$reliability of the studied indicator in patients with DISH

$\mathrm{P} 2 * *$ - reliability of the studied indicator in patients with AS

$\mathrm{P} 3 * * *$ - reliability of the studied indicator in patients with SP

$\mathrm{P} 4 * * * *$ - reliability of the studied indicator in patients with gout 
The individual values of s-RANKL in patients with DISH, SP, and AS gradually increased with age, while the values of this indicator decreased in adult controls ( $p$ $<0.05)$. The vast distribution of individual results was found in all studied groups of patients.

There is a significant relationship between s-RANKL and serum calcium, ionized calcium, serum phosphorus, uric acid, creatinine, and urea, in patients with DISH, AS, and $\mathrm{SP}(\mathrm{p}<0.01)$.

The s-OPG/s-RANKL ratio in patients with DISH and
AS is higher than that of the control subjects $(\mathrm{p}<0.05)$. The $\mathrm{s}-\mathrm{OPG} / \mathrm{s}-\mathrm{RANKL}$ ratio in patients with SP and gout is lower compared to the ratio in patients with DISH and AS $(\mathrm{p}<0.05)$, therefore we assume that patients with severe hyperostosis have a higher level of s-OPG compared to controls, patients with SP, and gout. The balance between osteogenesis and osteoclastogenesis is disturbed in favor of osteogenesis. All of the patient groups had lower values of the s-OPG/s-RANKL ratio compared to that of the healthy adult controls (Table 6).

Table 6. s-OC / s-RANKL and OPG / s-RANKL in patients with DISH, CP, AS, gout, adult, and controls in ng/ml.

\begin{tabular}{|l|l|l|l|l|}
\hline Patients & s-OC ng/ml & s-OPG ng/ml & s-RANKLng/ml & OPG/s-RANKL \\
\hline DISH & 6,37 & 14,73 & 0,197 & 77,77 \\
\hline AS & 7,27 & 21,95 & 0,091 & 79,89 \\
\hline SP & 1,19 & 7,58 & 0,2 & 37,91 \\
\hline Gout & 1,78 & 9,12 & 0,25 & 36,48 \\
\hline $\begin{array}{l}\text { Control group up to } \\
\text { 30 years of age }\end{array}$ & 1,78 & 11,89 & 0,083 & 143,25 \\
\hline $\begin{array}{l}\text { Control group over } \\
\text { 31 years of age }\end{array}$ & 1,22 & 5,04 & 0,08 & 63 \\
\hline
\end{tabular}

\section{DISCUSSION}

s-OPG and s-RANKL have key importance as markers for the assessment of bone metabolism [5, 19, 26, 27, 28]. Despite this fact, the metabolism has not been studied in DISH and in AS, which are typical diseases with newly formed bone and soft tissue ossification. Krysturkova et al. had reported that s-OPG in patients with DISH was not changed compared to controls, while the level of s-OC in the same patients was significantly higher $(\mathrm{p}<0.05)$ [21]. Bone alkaline phosphatase in patients with DISH was also significantly elevated $(\mathrm{p}<0.05)$, which correlates with the presence of osteopenia and osteoporosis in patients (elevated bone alkaline phosphatase is found in $14 \%$ of patients with DISH and $35 \%$ of patients with AS) [21]. The publication states that the level of bone alkaline phosphatase was higher in patients who had lower levels of s-OPG and s-OC.

$\mathrm{S}-\mathrm{OC}$ is one of the most sensitive biochemical markers for objectifying bone synthesis (29). Its study in patients with DISH is necessary in order to assess the condition of their bone metabolism and also its importance for the pathogenesis and diagnosis of the disease [26].

According to our results, the level of s-OC in patients with DISH was increased when compared to patients with SP and adult controls $(\mathrm{p}<0.001)$, but it was not higher than that of patients with AS and gout ( $\mathrm{p}>0.05)$. These results coincide with the data of Krysturkova et al. [21]. We found a large dispersion of individual values in patients with DISH, and $\mathrm{AS}$, as well as a rapid increase in mean values over the years, in comparison to those in patients with SP.

The level of s-OPG correlates significantly with the levels of serum and ionized calcium, phosphorus, alkaline phosphatase, and creatinine, which to us seemed probable due to the role that s-OPG occupies in the bone marrow.
What causes the increase in s-OPG in DISH and AS is difficult to assess. Hypothetically, this may be the result of a series of events, which are based on the damage of the spine (osteoporosis, compression fractures, hyperinsulinemia in metabolic diseases, etc.), which reduces the strength of the vertebrae and the body by some mechanism (most likely neuro-endocrine-cytokine), and an increase in the synthesis of OPG by osteoblasts in order to protectively form more bone and so the body adapts to the new changes. This hypothesis is supported by the opinion of Khisla, 2001, according to whom "the process of hyperostosis begins with the migration of osteoblasts to those places where new bone formation occurs"[30].

The s-OPG study can serve as an early diagnostic marker for DISH since in 8 patients who did not meet the Resnick and Mata criteria for the disease, we found significantly elevated values compared to those of patients with SP (mean values in DISH 6.37 vs 1.19 in SP). At the present time, with the current medical development, these studies cannot be carried out routinely, only in large university hospitals and research centers, but in the future, this may change. Individual values of s-OPG and s-RANKL within patients with DISH, AS, and SP gradually increases with age, while in adult controls, they decrease. With the current development of medical science, it is not possible to give an unambiguous answer as to why the values of s-OPG and s-RANKL are increased in patients with DISH and AS. Hypothetically, it is possible that the increase in s-RANKL is a response to the initial increased bone synthesis by metaplasing the monocyte/macrophage cell precursors into multinucleated osteoclasts in order to restore the balance between bone synthesis and bone degradation. 


\section{CONCLUSION:}

The balance between osteogenesis and osteoclastogenesis is disturbed in favor of osteogenesis in patients with DISH and AS but not in those with gout and spondylosis. Our studies show that changes in bone metabolism are similar in patients with DISH and ankylosing spondylitis. Further research is needed to look for a common pathogenetic pathway linking degenerative and inflammatory rheumatic diseases of the axial skeleton.

\section{Abbreviations:}

AS - Ankylosing spondylitis

DISH - Diffuse idiopathic skeletal hyperostosis

ELISA - Enzyme-linked immunosorbent assay

kD - KiloDaltons

$\lambda$ - Lamda
NFATc1 - Nuclear factor of activated T-cells cytoplasmic 1

NF-kB - Nuclear factor kappa-light-chain-enhancer

nm - nanometer

pg/ml -picogram/ milliliter

RA - Rheumatoid arthritis

RANK - The receptor activator of nuclear factor-kapa B

RANKL - The receptor activator of nuclear factor-kapa B ligand

SD -Standart deviation

SP - spondylosis

$\mathbf{s - O C}$ - osteocalcin

s-OPG - serum osteoprotegerin

SPSS - Statistical Package for the Social Sciences

TNF - Tumor necrosing factor

TRAIL - Tumor necrosis factor-related apoptosis-inducing ligand

\section{REFERENCES:}

1. Childs SG. Diffuse idiopathc skeletal hyperostosis: Forestier's Disease. Orthop Nurs. 2004 Nov-Dec; 23(6):375-82. [PubMed]

2. Holgate RL, Steyn M. Diffuse idiopathic skeletal hyperostosis: Diagnostic, clinical, and paleopathological considerations. Clin Anat. 2016 Oct;29(7):870-7. [PubMed]

3. Eser P, Bonel H, Seitz M, Villiger PM, Aeberli D. Patients with diffuse idiopathic skeletal hyperostosis do not have increased peripheral bone mineral density and geometry. Rheumatology (Oxford). 2010 May; 49(5):977-81. [PubMed]

4. Kuperus JS, Mohamed Hoesein FAA, de Jong PA, Verlaan JJ. Diffuse idiopathic skeletal hyperostosis: Etiology and clinical relevance. Best Pract Res Clin Rheumatol. 2020 Jun; 34(3):101527. [PubMed]

5. Boyce BF, Xing L. Biology of RANK, RANKL, and osteoprotegerin. Arthritis Res Ther. 2007; 9 Suppl 1 (Suppl 1):S1. [PubMed]

6. Pérez-Sayáns M, SomozaMartín JM, Barros-Angueira F, Rey JM, García-García A. RANK/RANKL/ OPG role in distraction osteogenesis. Oral Surg Oral Med Oral Pathol Oral Radiol Endod. 2010 May;109(5): 679-86. [PubMed]

7. Kalkan R, Altarda M, Tosun O. RANKL is a new Epigenetic Biomarker for the Vasomotor Symptom During Menopause. Balkan J Med Genet. 2020 Aug 26;23(1):51-56. [PubMed]
8. Bucay N, Sarosi I, Dunstan CR, Morony S, Tarpley J, Capparelli C, et al. osteoprotegerin-deficient mice develop early onset osteoporosis and arterial calcification. Genes Dev. 1998 May 1;12(9):1260-8. [PubMed]

9. Tsukasaki M, Asano T, Muro R, Huynh NC, Komatsu N, Okamoto $\mathrm{K}$, et al. OPG Production Matters Where it happened. Cell Rep. 2020 Sep 8;32(10):108124. [PubMed]

10. Deligiorgi MV, Panayiotidis MI, Griniatsos J, Trafalis DT. Harnessing the versatile role of OPG in bone oncology: counterbalancing RANKL and TRAIL signaling and beyond. Clin Exp Metastasis. 2020 Feb;37(1):13-30. [PubMed]

11. Harper E, Forde H, Davenport C, Rochfort KD, Smith D, Cummins PM. Vascular calcification in type-2 diabetes and cardiovascular disease: Integrative roles for OPG, RANKL and TRAIL. Vascul Pharmacol. 2016 Jul; 82:30-40. [PubMed]

12. Silva I, Branco JC. Rank/ Rankl/opg: literature review. Acta Reumatol Port. 2011 Jul-Sep;36(3): 209-18. [PubMed]

13. Clézardin P. [The role of RANK/RANKL/osteoprotegerin (OPG) triad in cancer-induced bone diseases: physiopathology and clinical implications] [in French] Bull Cancer. 2011 Jul;98(7):837-46. [PubMed]

14. Stupphann D, Rauner M, Krenbek D, Patsch J, Pirker T, Muschitz C, et al. Intracellular and surface RANKL are differentially regulated in patients with ankylosing spondylitis. Rheumatol Int. 2008 Aug;28(10):987-93. [PubMed]

15. Nitta K, Akiba T, Uchida K, Kawashima A, Yumura W, Kabaya T, et al. The progression of vascular calcification and serum osteoprotegerin levels in patients on long-term hemodialysis. Am J Kidney Dis. 2003 Aug; 42(2):303-9. [PubMed]

16. Browner WS, Lui LY, Cummings SR. Associations of serum osteoprotegerin levels with diabetes, stroke, bone density, fractures, and mortality in elderly women. J Clin Endocrinol Metab. 2001 Feb;86(2): 631-7. [PubMed]

17. Harper E, Rochfort KD, Smith D, Cummins PM. RANKL treatment of vascular endothelial cells leading to paracrine pro-calcific signaling involves ROS production. Mol Cell Biochem. 2020 Jan;464(1-2):111-117. [PubMed]

18. Eghbali-Fatourechi G, Khosla S, Sanyal A, Boyle WJ, Lacey DL, Riggs BL. Role of RANK ligand in mediating increased bone resorption in early postmenopausal women. $J$ Clin Invest. 2003 Apr;111(8):1221-30. [PubMed]

19. Simonet WS, Lacey DL, Dunstan CR, Kelley M, Chang MS, Lüthy R, et al. Osteoprotegerin: a novel secreted protein involved in the regulation of bone density. Cell. 1997 Apr 18;89(2):309-19. [PubMed]

20. Hermann KG, Bollow M. Rethinking diffuse idiopathic skeletal 
hyperostosis. Rheumatology (Oxford). 2014 Nov;53(11):1917-9. [PubMed]

21. Olmedo-Garzón FJ, Ruiz Ollero A. Diffuse Idiopathic Skeletal Hyperostosis and Ankylosing Spondylitis: Comment on the Article by Latourte et al. Arthritis Care Res (Hoboken). 2019 Aug;71(8):11481150. [PubMed]

22. Hofbauer LC, Khosla S, Dunstan CR, Lacey DL, Boyle WJ, Riggs BL. The roles of osteoprotegerin and osteoprotegerin ligand in the paracrine regulation of bone resorption. J Bone Miner Res. 2000 Jan;15(1):2-12. [PubMed]

23. Schett G, Kiechl S, Redlich K, Oberhollenzer F, Weger S, Egger G, et al. Soluble RANKL and risk of nontraumatic fracture. JAMA. 2004
Mar 3;291(9):1108-13. [PubMed]

24. Li CH, Ma ZZ, Jian LL, Wang XY, Sun L, Liu XY, et al. Iguratimod inhibits osteoclastogenesis by modulating the RANKL and TNF-á signaling pathways. Int Immunopharmacol. 2021 Jan;90:107219. [PubMed]

25. Qi D, Liu H, Sun X, Luo D, Zhu M, Tao T, et al. Pristimerin Suppresses RANKL-Induced Osteoclastogenesis and Ameliorates Ovariectomy-Induced Bone Loss. Front Pharmacol. 2021 Jan 15;11:621110. [PubMed]

26. Lian JB, Gundberg CM. Osteocalcin. Biochemical considerations and clinical applications. Clin Orthop Relat Res. 1988 Jan;(226): 267-91. [PubMed]
27. Leibbrandt A, Penninger JM. RANKL/RANK as key factors for osteoclast development and bone loss in arthropathies. Adv Exp Med Biol. 2009;649:100-13. [PubMed]

28. Kalichman L, Kobyliansky E. Radiographic hand osteoarthritis and serum levels of osteocalcin: cross-sectional study. Rheumatol Int. 2010 Jun;30(8):1131-5. [PubMed]

29. Smith C, Voisin S, Al Saedi A, Phu S, Brennan-Speranza T, Parker L, et al. osteocalcin and its forms across the lifespan in adult men. Bone. 2020 Jan;130:115085. [PubMed]

30. Khosla S. Minireview: the OPG/RANKL/RANK system. Endocrinology. 2001 Dec;142(12):5050-5. [PubMed]

Please cite this article as: Geneva-Popova M, Popova S. Study of serum Osteoprotegerin and Receptor Activator of Nuclear Factor Kappa-B Ligand in patients with rheumatic diseases. J of IMAB. 2021 Oct-Dec;27(4):4170-4177.

DOI: https://doi.org/10.5272/jimab.2021274.4170

Received: 19/05/2021; Published online: 17/12/2021

Address for correspondence:

Mariela Genceva Geneva-Popova

Medical University - Plovdiv, Faculty of Medicine, Propaedeutics of Internal Diseases; UMHAT “Sveti Georgi” Plovdiv, Rheumatology;

E-mail: genevapopova@yahoo.com 